\title{
Study on the Construction of Teachers' Competency Standards in Applied Universities
}

\author{
Tian Pei
}

Xi'an Peihua University, Xi’an, Shannxi, 710125

Keywords: Construction of Teachers' Competency Standards, Applied Universities

\begin{abstract}
Talents are the primary resources for school development. Constructing a high-level applied faculty is the first need to build a high-level applied university. The achievements of the faculty building have guaranteed the all-round development of various undertakings in schools and have effectively promoted the discipline construction, professional construction, personnel training and social services, laying the foundation for the sustainable development of schools. However, there are still some problems which need to be solved urgently in the construction of the teaching staff in the school. In addition, the construction of the applied faculty should be further strengthened. The construction of "double-qualified" teaching staff is the basic way to enhance the teaching ability of teachers and achieve the goal of talent cultivation in applied-typed colleges. Based on the connotation of applied undergraduate and "double teacher" teachers, this paper analyzes the meaning and current situation of the construction of "double teacher" teachers in applied undergraduate colleges and puts forward some suggestions on how to strengthen the "dual teacher" in the construction of teaching staff.
\end{abstract}

\section{Introduction}

Looking at the practice of building and developing school teachers, we can see that the overall status of teachers has been greatly improved. The total number of faculty members has increased substantially, and the structure has been continuously optimized. The quality has been markedly improved, and the overall strength of academic leaders has been markedly enhanced. Outstanding young teachers should stand out [1]. Applied undergraduate is relatively common undergraduate terms, which is the transition from elite to popular and popularization of higher education from academic and research to the type of application results. Applied undergraduate education is a kind of undergraduate education, which refers to the "application" as the guide in close connection with the regional economy and market demand, which is training with strong theoretical ability, practical ability to solve problems, and the ability to apply undergraduate talents. The term "dual-type" was first evolved from the "dual system" vocational education mode proposed by Germany. Subsequently, the U.S. occupation education movement put forward the combination of production, study and research as well as the "CBE" model. Britain put forward the model of "alternative study" and "modern apprenticeship." Japan proposed the mode of "industry-university cooperation." Australia proposed the "TAFE" model, etc. . From a domestic point of view, Wang Yicheng (1990) in the "China Education Newspaper" on the construction of "double division" specialist teachers first clearly put forward the "double teacher" concept [2]. According to "double certificate" theory, both professional and technical qualification certificates and professional qualification certificates are considered on the basis of having a teacher qualification certificate [3].

\section{Significance of Teaching Staff Building in Applied Universities}

"Dual-quality" theory contains both good personal and physical qualities and professional moral qualities. The theory of "dual abilities" holds that both of them have profound theoretical teaching ability and solid practical guiding ability [4]. Combined with the characteristics of "applied, practical and operational" applied undergraduate, we think that "double teacher" refers to teachers who have both "double certificates", "dual qualities" and "dual abilities". Work accumulated a 
wealth of scientific theoretical knowledge and business experience can flexibly apply these knowledge and experience in theoretical teaching and practical guidance.

Teaching staff construction is the most basic connotation construction of higher education. First of all, the construction of "double-qualified" teaching staff is an important prerequisite to achieve the goal of talent cultivation in applied-oriented colleges and universities. Second, the construction of "double-qualified" faculty is the basic way to cultivate talents in applied undergraduate colleges. Third, the construction of "double-qualified" teachers helps to improve the quality of personnel training and the employment rate of students [5]. The employment rate is an important indicator of the quality of personnel training. "Double-qualified" teachers can better guide students' experiments, internships and practical training by improving their practical guidance ability. Besides, it can improve the coordination between school and enterprises.

\section{Status of Teachers' Construction in Applied Universities}

Since China promulgated the Law on Vocational Education in May 1996, vocational education has made an important contribution to promoting economic and social development and promoting employment. In May 2014, the "Decision of the State Council on Accelerating the Development of Modern Vocational Education" proposed the implementation of the "double-qualified" faculty construction project [6]. "Opinions of Guangdong Province on Establishing a Pilot Province for Comprehensive Reform of Modern Vocational Education" in January 2015 pointed out that implementing the "Project of Strong Teachers in Modern Vocational Education" and promoting the cultivation of "double-qualified" teachers by high-level schools and large and medium-sized enterprises. It can support the law in accordance with the rules to obtain a reasonable return or at the enterprise price into shares. It can be seen that the construction of "double-qualified" teachers has drawn great attention from the government [7]. And it is very necessary to speed up the research on the standards, objectives and paths for the construction of "double-qualified" teachers.

In January 2012, the Measures for the Implementation of Qualification Assessment for Undergraduate Teaching in Universities and Colleges put forward the following: "There should be a certain number of teachers in the teaching staff who possess professional occupational qualifications and working experience." Accelerate the construction of "double-qualified" teaching staff, speed up the introduction of the corresponding "double teacher" teacher construction, assessment and incentive programs can greatly promoted the enthusiasm of teachers to strengthen their own building, the number of "double-qualified" teachers gradually increased while the quality of teachers is obviously improved [8]. Scholars also actively discussed the concept, existing problems, construction measures and assessment standards of "dual-qualified" teachers. Some scholars combined their own research fields to focus on the training path of "dual-qualified" teachers. All of these achievements provide an important reference for carrying out the construction and development of "double-qualified" teachers.

At present, the construction of "double-qualified" teachers in applied undergraduate colleges is still under exploration and there are still some problems in practical construction. First, no uniform definition of the evaluation criteria is not clear. Second, teacher education requirements and application-oriented practice requirements conflict. Education background is good, while highly educated college teachers are often lack of practical experience. Third, part-time teachers in enterprises in the professional teaching ability is poor, and especially the professional theory teaching and class education and management urgently need to be strengthened. Fourth, the practice of post-job, job-attachment training and other practical measures to enhance the flow of messes, most of the top-notch practice of teachers just ask the business to help seal the seal, but did not really participate in the practice [9]. Fifth, enterprises take into account the trade secrets, who do not want to participate in the practice of teachers to arrange real work tasks. Sixth, a small number of cooperative enterprises are willing to provide practical positions and professional counterparts. Finally, there is insufficient motivation for participation due to the lack of incentives. 


\section{Ways to Improve Faculty in Applied Universities}

In order to strengthen the construction of teaching staff and optimize the structure of teaching staff, applied undergraduate colleges should encourage teachers to take part in the practice of enterprises as the main channel, and make "double teacher" evaluation standards based on the actual situation in schools [10].

1) College teachers qualifications.

Teachers should be officially signed employment contracts with the school on the job of workers, while the lecturer has made a series of titles of college teachers with a teacher certificate.

2) Professional and technical qualifications.

Through the national unified organization of intermediate and above professional and technical position examination or various types of qualifications examination, and obtained mid-level above qualification certificate. Such as accountants, auditors, economists, certified public accountants, human resource managers, safety engineers.

3) Practice conditions.

First, the past five years in more than two years (which can be calculated) in the professional work experience in the profession, can independently guide students in professional practice training activities. Second, participating in enterprise practice costs more than two months, and practice log records are completed, the practice is completed, and qualified by the enterprise assessment, which is capable of professional core curriculum theory and practice, practical teaching. Third, in the past five years, he has presided over (or mainly participated in) applied technology research or jointly filed research projects with enterprises, and the research achievements have been well applied in the enterprises.

Applied undergraduate colleges and universities should be based on their own actual situation to develop a reasonable and feasible "double teacher" construction of teaching staff [7]. First, the teaching level of "double-qualified" teachers, especially the practical teaching level, should be significantly improved, which can be reflected in the employment rate of students. Second, the overall level of scientific research in schools, especially that of production, teaching and research, has been significantly improved. Thirdly, the annual growth rate of "dual-type" teachers has reached about $10 \%$. Fourth, the total number of "double-qualified" teachers reaches about $60 \%$ level after a five-year construction.

Strengthen TPACK ability training

In the information society, the ability to use information technology has gradually become an important foundation and basis for teachers' teaching ability. TPACK (Technological Pedagogical Content Knowledge), that is, integration of technology disciplines teaching knowledge, is a kind of knowledge and skills of interdisciplinary teaching content, teaching methods and techniques, which includes three core elements: subject content (CK), pedagogy (PK), technology (TK); four composite elements: PCK, TCK, TPK) with a comprehensive, situational, silent, volatile, practical and other characteristics [6]. Therefore, teachers can study the application of information technology in teaching by means of case study, demonstration, participation in teaching, exchange and discussion, so as to enhance TPACK-based technology integration teaching ability.

Clearly identify the standard, and strengthen the "double division" awareness.

Applied undergraduate institutions should combine their own practical, practical characteristics and professional training objectives, drawing on domestic and foreign and related institutions of construction experience. Combined with the practical experience of teachers and research level, the development of "double-qualified" teachers identified standards, and lead teachers toward standard development.

Improve the training system, innovation and training mode.

Through the "going out, please come in" approach, arrangements for young teachers to go to work on the job, job attachment, research, job rotation, following classes, hiring business, government management experts, the backbone to school and class or as a young teacher "band master", enrich the "double teacher" structure and training model.

Deepen the cooperation between schools and enterprises, strengthen the combination of work 
and study.

First of all, teachers should be encouraged to give full play to their own theoretical and scientific research advantages with a total of compiling teaching materials, sharing courses, create a professional; Second, teachers should be encouraged to actively participate in and seriously take the post practice, and good assessment reward work; Schools should combine the characteristics of various professions to carry out the combination of work and study so as to form a good mechanism of cooperation in production, teaching and research cooperation [3].

To expand the construction of internship base inside and outside the school to consolidate the experimental training platform.

Applied undergraduate colleges and universities should actively expand more cooperation between schools and enterprises as a platform for practical teaching and teachers practice exercises, and strive to build a platform for exchange of talents, mutual benefits, mutual benefit, mutual training and mutual exchange between schools and enterprises.

Enhance teacher education, improve the professional structure of teachers.

Encourage the existence of professional mismatch, strong practical guidance, but academic level teachers and other issues to actively enhance the academic level, and give the appropriate subsidies to improve the professional structure of teachers [2].

\section{Strengthen the Training of Teachers' Innovative Ability and Professional Quality}

Schools with the school-enterprise cooperation platform enhance innovation and professional quality of teachers training and improve the practical ability of teachers to apply training. The enterprise is an invaluable resource and an important platform for enhancing teachers 'practical teaching ability. The school regularly organizes teacher rotation training by focusing on advanced skills and understanding of the industry by organizing teachers' training bases outside the university, training of counterparty enterprise workstations and cooperation with key project projects of enterprises. Demand and development trends can improve the quality of application. To achieve the double identity of school-enterprise staff, curriculum construction, the backbone of the two, so that college teachers and business leaders work together to develop the design of course teaching system, teaching and production practice to achieve two-way integration. Launched the teacher's "visiting plan" and its supporting preferential policies to encourage professional teachers to obtain professional qualifications and establish a long-term mechanism of contact between schools and social counterparts [4].

The grass-roots units in the school have conscientiously taken the building of an applied faculty as an important task and pushed them forward with more vigorous measures and more pragmatic style. All grass-roots units should do a good job in their teacher training programs according to the actual situation. They should attach importance to the cultivation of professional teachers' theory and professional ability, as well as the construction and training of experimental teachers. They should integrate teacher resources within and outside the school. Broaden sources of professional teachers actively introduce the community, business professionals into professional education, the establishment of a combination of high-level and application-oriented teachers [8]. In short, the construction of applied faculty is the need of school development, the need of cultivating applied undergraduate talents, and the need of cultivating students' innovative ability and practical ability. Only by taking active and effective measures to make great progress in the construction of applied teaching faculty in the school can we provide effective personnel protection for building a high-level university.

\section{References}

[1] McSharry E, Lathlean J. Clinical teaching and learning within a preceptorship model in an acute care hospital in Ireland; a qualitative study [J]. Nurse Education Today, 2017, 51: 73-80.

[2] Darling-Hammond L. Teacher education around the world: What can we learn from 
international practice? [J]. European Journal of Teacher Education, 2017: 1-19.

[3] Zhang D, Wang Q, Stegall J, et al. The Construction and Initial Validation of the Student Teachers' Efficacy Scale for Teaching Students with Disabilities [J]. Remedial and Special Education, 2017: 0741932516686059.

[4] Torrance D, Forde C. Redefining what it means to be a teacher through professional standards: Implications for continuing teacher education [J]. European Journal of Teacher Education, 2017, 40(1): 110-126.

[5] Geng C. On the Teaching Innovation of Business English Teaching: A study on Multimodal Communicative Competence of Ethnic Universities [J]. Theory and Practice in Language Studies, 2017, 7(4): 322.

[6] Winberg C, Winberg S. Pedagogical competence for engineering educators: Re-conceptualizing teaching portfolios[C]//Global Engineering Education Conference (EDUCON), 2017 IEEE. IEEE, 2017: 431-436.

[7] Lin K Y, Williams P J. Two-stage hands-on technology activity to develop preservice teachers' competency in applying science and mathematics concepts[J]. International Journal of Technology and Design Education, 2017, 27(1): 89-105.

[8] Baturay M H, Gökçearslan Ş, Ke F. The relationship among pre-service teachers' computer competence, attitude towards computer-assisted education, and intention of technology acceptance [J]. International Journal of Technology Enhanced Learning, 2017, 9(1): 1-13.

[9] Han I. Conceptualisation of English teachers' professional identity and comprehension of its dynamics [J]. Teachers and Teaching, 2017, 23(5): 549-569.

[10] Bowen T. Assessing visual literacy: a case study of developing a rubric for identifying and applying criteria to undergraduate student learning [J]. Teaching in Higher Education, 2017: 1-15. 